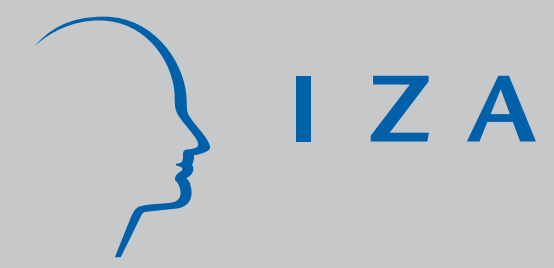

IZA DP No. 315

On Price-Setting for Identical Products in Markets without Formal Trade Barriers

Wolter H.J . Hassink

Ronald Schettkat

J une 2001 


\title{
On Price-Setting for Identical Products in Markets without Formal Trade Barriers
}

\author{
Wolter H.J. Hassink \\ Department of Economics, Utrecht University \\ Ronald Schettkat \\ Department of Economics, Utrecht University
}

Discussion Paper No. 315
June 2001

IZA

P.O. Box 7240

D-53072 Bonn

Germany

Tel.: +49-228-3894-0

Fax: +49-228-3894-210

Email: iza@iza.org

This Discussion Paper is issued within the framework of IZA's research area General Labor Economics. Any opinions expressed here are those of the author(s) and not those of the institute. Research disseminated by IZA may include views on policy, but the institute itself takes no institutional policy positions.

The Institute for the Study of Labor (IZA) in Bonn is a local and virtual international research center and a place of communication between science, politics and business. IZA is an independent, nonprofit limited liability company (Gesellschaft mit beschränkter Haftung) supported by the Deutsche Post AG. The center is associated with the University of Bonn and offers a stimulating research environment through its research networks, research support, and visitors and doctoral programs. IZA engages in (i) original and internationally competitive research in all fields of labor economics, (ii) development of policy concepts, and (iii) dissemination of research results and concepts to the interested public. The current research program deals with (1) mobility and flexibility of labor markets, (2) internationalization of labor markets and European integration, (3) the welfare state and labor markets, (4) labor markets in transition, (5) the future of work, (6) project evaluation and (7) general labor economics.

IZA Discussion Papers often represent preliminary work and are circulated to encourage discussion. Citation of such a paper should account for its provisional character. 
IZA Discussion Paper No. 315

June 2001

\section{ABSTRACT \\ On Price-Setting for Identical Products in Markets without Formal Trade Barriers*}

This paper investigates price-setting for truly homogenous products sold in markets without any formal trade barriers. We use data from IKEA, a furniture company selling identical products in an identical shopping environment in different EU countries. We get four remarkable outcomes: 1) The law of one price does not hold. 2) Country-specific effects of non-tradable cost components are important. 3) Pricing to the market surely occurs but price discrimination is limited by incomplete information. 4) The unexplained part of betweencountry price variation for identical products is about $75 \%$ which leaves most of the intercountry price variation unexplained.

JEL Codes: D4

Keywords: Price setting, price discrimination

Wolter Hassink

Faculty of Social Sciences

Department of Economics

Utrecht University

P.O.Box 80140,

NL-3508 TC Utrecht

The Netherlands

Tel.: +31302531115

Fax: +31302533992

Email: w.hassink@fss.uu.nl

\footnotetext{
* We are grateful to our former student Istvan Koij and various colleagues in EU-countries for collecting the IKEA-catalogues. Istvan skillfully constructed the data set.
} 


\section{Introduction}

The integration of national economies into one European Market demolished all formal trade barriers within the European Union, which creates a unique opportunity to investigate pricing behavior. If the European Union would form one integrated market, the 'law of one price'(LOP) would predict that homogenous products are sold at the same common-currency price in every national market. However, past studies (e.g., Isard 1977, Kravis and Lipsey 1978, Knetter 1989, Goldberg and Verboven 1998, Froot, Kim and Rogoff 1995; for overviews: Rogoff 1996, Goldberg and Knetter 1997) found severe violations of the LOP. This empirical result may be caused by a multitude of variables: (1) goods are seldom homogenous, (2) the service and shopping environment is heterogeneous (bundling is different), (3) tariff trade-barriers may exist, (4) non-tariff trade-barriers may exist, (5) transport and information costs are relevant, (6) nontradable costs components (factor costs) differ, (7) taxes (such as the VAT) differ, (8) expected exchange rate variations together with 'menu costs' may cause national price variation, (9) competition may differ, (10) profit-maximizing firms discriminate between national markets for specific product groups (pricing to the market, Krugman 1987), (11) profit-maximizing firms discriminate between national markets for specific products, (12) price-setting is arbitrarily.

'Ideally, a test of the LOP would compare prices for two transactions in which the nationality of the buyer is the only difference in transaction characteristics. In practice, the identical goods assumption is almost surely violated to some degree in available data' (Goldberg and Knetter 1997: 1247). Isard (1977) and Knetter (1989), Goldberg and Verboven (1998) and others found substantial violations of the LOP but their estimates were based on prices of goods in narrowly defined industries (up to seven digit industry classification) or on complex products. But even at 
the most dis-aggregated level of the industry classification, products may not be homogenous over countries, a problem inherent in PPP measures. Complex products such as cars as in the study of Goldberg and Verboven are usually not exactly identical in different countries. Subsequent research tried to focus on homogenous products of specific firms that are sold in various countries. Most famous is the Economist's 'Big-Mac-Index' used as an example for a 'truly homogeneous' product, although it may be bundled differently in different places (Rogoff 1996) ${ }^{1}$. Ghosh and Wolf (1994) used data of prices of the magazine 'The Economist'over various countries. They show that departures of the common-currency price are the effect of exchange rate variations rather than intentional price discrimination. Knetter (1997) also using prices of the 'Economist' claimed that price differentials within continental Europe and Scandinavia are small but that prices in these countries are substantially different from those in the UK and the US. Differences in the price-elasticity of demand for 'The Economist' lead according to Knetter to price discrimination between the markets. In other words, 'The Economist' is priced to the market. These studies illuminated price-setting for one homogenous product in various national markets but they are limited to one specific product. This paper continues this line of research using price information on various homogenous products sold by a single firm in a standardized environment with standardized services in various national markets without any formal trade barriers between these markets.

We created a unique data set free of noise because we perfectly control for product quality (variable 1 from above) the seller characteristics and bundling (variable 2). We collected data on 222 products sold by IKEA, a worldwide operating furniture company selling identical products 
in exactly the same shopping environment, in 10 EU countries, which form legally one market and which demolished all formal trade-barriers (3). Non-formal trade barriers (4) may still exists and transport and information costs (5) may reduce regional arbitrage and may allow non-tradable cost components (6) such as wages, insurance costs, rents and taxes (7) to affect regional prices. We use data for 1997 when national currencies were not yet fixed to the EURO, i.e. expected exchange variations (8) may also affect national price levels. Under the 'strong PPP rule' (Dornbusch 1987) LOP holds in any case but under the 'weak PPP rule' (Dornbusch 1987) variables 4 to 9 may well affect national prices but pricing is still cost based. Variables 10 to 11 , however, investigate pricing to demand situations (Varian 1989) where firms discriminate between buyers at increasing degrees of sophistication caused by increasing information requirements.

We find, as others before, that the LOP definitely does not hold for the EU common market and that this fact cannot be explained with the arguments 1 to 10 listed above. Instead, we find some evidence for price discrimination between markets but also for price-setting which may result from the sellers incomplete information about the national product-specific demand functions.

This paper is organized as follows: Section 2 outlays the theory and develops the hypotheses to be tested in Section 4 after the description of the data (Section 3). Section 5 concludes

and Canada but costs roughly 50 cents in Holland and Italy. 


\section{Brief discussion of the theory}

In principle, price-setting can be based on costs or demand variables (for an overview: Blinder et al. 1998). Both are integrated in the perfect market model: competition pushes the price down to marginal costs, which the sellers have to meet. Consumers capture the rent. At the other extreme is a monopolist perfectly informed about the demand functions of individual customers charging each customer exactly his reservation price [first degree price discrimination, Pigou 1920, Shapiro and Varian 1999 (page 39) label this form of price discrimination 'personalized pricing' and mention that the firm's informational problems may be substantially reduced by the data made available through the internet] and thus capturing $100 \%$ of the consumer rent. Such a perfect pricing strategy' requires perfect information on the side of the seller but at the same time 'perfect' non-information or other trade barriers on the side of the buyers because otherwise arbitrage would eliminate price discrimination. In actual markets, both sellers and buyers face information imperfections and we expect actual markets to be positioned somewhere between these extremes.

In customer markets (Okun 1981) sellers put price tags on their products and buyers shop around (searching) for a low but given their information costs not necessarily for the lowest price. Price tags take away the possibility of first-degree price discrimination but they still allow for interregional (inter-country) price discrimination (so-called third degree price discrimination, Pigou 1920). ${ }^{2}$ A profit-maximizing monopolist will set the price at marginal revenue (MR) divided by one minus the price-elasticity $(\eta)$ of demand $[P=M R /(1-\eta)]$. Therefore, applying inter-regional price discrimination to maximize the firm's overall profit requires sufficiently different demand 
function in the regional markets and knowledge about the regional demand functions. Sellers are usually insecure about the demand function for their product (Stiglitz 1991) and thus cannot exactly determine the profit-maximizing price but they may have rough ideas about the popularity of certain products in different regional markets.

Exchange rate volatility is another source of costs for internationally operating firms. Gosh and Wolf (1994) argue that observed inter-country price differences for a homogeneous good expressed in a common currency may be caused by (unexpected) exchange rate variations together with 'menu costs' and thus sticky prices. Therefore, observed price differences expressed in a common currency may be unintended or may reflect a risk premium for expected exchange rate variations.

In general, the common-currency price ( $\mathrm{p}^{*}$ ) for a homogenous good (subscript i) sold in different countries (subscript c) can be expressed as:

(1) $\quad \mathrm{p}_{\mathrm{i}, \mathrm{c}}^{*}=\mathrm{k}_{\mathrm{i}, \mathrm{o}} \mathrm{e}_{\mathrm{c}} * \gamma_{\mathrm{i}, \mathrm{c}} \mathrm{D}$

where $\mathrm{k}_{\mathrm{i}, \mathrm{o}}$ is the cost of item $\mathrm{i}$ in the country of origin, $\mathrm{e}_{\mathrm{c}}$ is the nominal exchange rate $\left(\mathrm{e}_{\mathrm{c}}=\right.$ home currency / origin currency), $\gamma$ is a mark-up $\geq 1$, and $\mathrm{D}$ is a vector of country dummies, ${ }^{*}$ indicates the common-currency expression.

elasticities. Third degree refers to regional price discrimination. 
Since the cost of the product in the country of origin $\left(\mathrm{k}_{\mathrm{i}, \mathrm{o}}\right)$ is not observable for us, we approximate equation (1) with the following expression:

$$
\mathrm{p}_{\mathrm{i}, \mathrm{c}}^{*}=\mathrm{p}_{\mathrm{i}, \mathrm{*}}^{*} * \beta_{\mathrm{i}, \mathrm{c}} \mathrm{D}
$$

or in logs:

(1") $\quad \ln \left(\mathrm{p}_{\mathrm{i}, \mathrm{c}}^{*}\right)=\ln \left(\mathrm{p}_{\mathrm{i} . .}^{*}\right)+\beta_{\mathrm{i} . \mathrm{C}} \mathrm{D}$

where $\mathrm{p}_{\mathrm{i}, \text {,. }}^{*}$ is the mean common-currency price of item $\mathrm{i}$ in the selected countries and $\beta_{\mathrm{i}, \mathrm{c}}$ is a country-specific price deviation for item i.

We summarize the theoretical discussion in four hypotheses allowing consecutively for more price variation. The first hypothesis is the most rigid and does not allow for any price variation (LOP or the strong PPP version). The second hypothesis allows for systematic country-specific variation in prices (weak PPP version). The third hypothesis allows for 'pricing to regional markets' (third degree price discrimination) and the fourth hypothesis allows for second degree price discrimination, i.e. for country-product price discrimination. These hypotheses require different restrictions on the $\beta_{\text {ic }}$ which are the following: 
Hypothesis 1: Law of one price or strong PPP version

The EU countries form one integrated market and prices expressed in a common currency are the same for identical goods in all countries.

In equation ( 1 ") the restriction $\beta_{\mathrm{i}, \mathrm{c}}=0$ for all items would apply, i.e. no common-currency price differences for the same good between countries.

\section{Hypothesis 2: Country-specific price setting (relative LOP) or weak PPP version}

Prices for all goods differ systematically between countries, i.e. regional arbitrage is imperfect and the national markets are separate markets for several potential reasons:

a) The costs of the non-tradable part of the product costs differ (i.e., labor costs, storage costs, value added taxes, rents etc.)

b) Exchange rate volatility leads to prices expressed in a common currency which differ systematically between countries

In equation (1") the restriction $\beta_{\mathrm{i}, \mathrm{c}}=\beta_{\mathrm{j}, \mathrm{c}}$ would apply, i.e. all goods would carry the same country-specific relative price effect.

\section{Hypothesis 3: Pricing to the market (mach I) or third degree price discrimination}

Firms may use knowledge of consumer preferences for specific product groups to pricediscriminate between countries by product groups. I.e., in one country consumers may have a high preference for kitchen furniture but for sofas their demand function may be highly price elastic whereas in another country the reverse relations may apply. Differentiating prices between countries by product groups will then maximize the profits of an internationally operating firm if regional arbitrage is difficult. 
In equation ( 1 ") the restriction $\beta_{\mathrm{i}, \mathrm{c}}=$ constant $\forall \mathrm{i} \in \mathrm{g}$ (where $\mathrm{g}$ indicates a specific product group) would hold. That is that all products belonging to a specific product group would carry the same country-specific relative price effect.

\section{Hypothesis 4: Pricing to the market (mach II) or second degree price discrimination}

This form of price discrimination requires prices to be set according to country-specific demand conditions for each individual product. The assumption is that preferences between countries not only differ by product groups but that they differ for specific products. A specific sofa, for example, my be particularly attractive for Italians but not for Germans whereas the reverse may be true for another sofa. The information requirements are very high, since the seller must now know the country-specific demand function for individual products and not only for a product group. To evaluate this hypothesis requires panel data and with the assumption of constant national differences for preferences we can actually test this hypothesis.

For a profit-maximizing firm with price setting the power the price will be set at $\mathrm{P}=\mathrm{MR} 1 /(1-\eta)$ and we expect relative prices to differ between countries according to the differences in price elasticity.

(2) $\frac{p_{i, c}^{*}}{p_{i, \bullet}^{*}}=\frac{M R_{i, c}}{M R_{i, \bullet}} \frac{\left(1-\eta_{i, \bullet}\right)}{\left(1-\eta_{i, c}\right)}$

where $\mathrm{P}_{\mathrm{i}, \mathrm{c}}^{*}$ is the common-currency price of item $\mathrm{i}$ in country c, MR is marginal revenue and $\eta$ is the price elasticity of demand.

In the country with the (absolutely) lower price elasticity of demand for item $i$ it is expected that a higher price than the mean price will be charged. Close to profit-maximum the marginal revenue 
is moving against zero but assume that it is still positive and in country c equal to the mean, equation (2) then becomes:

$$
\frac{p_{i, c}^{*}}{p_{i, \bullet}^{*}}=\frac{\left(1-\eta_{i, \bullet}\right)}{\left(1-\eta_{i, c}\right)}
$$

Assuming further that price elasticities are constant over time we expect under second degree price discrimination relative prices to remain constant over time. In other words, the difference in relative prices of the same item between two years should be roughly zero.

\section{The data}

To test the four hypotheses, we collected price data on 222 items sold by IKEA, an internationally operating furniture company, from the 1998 catalogues (prices valid from August 1997 until August 1998). Although IKEA operates world-wide, we restricted our sample to countries belonging to the European Union forming a common market without any formal trade barriers.3 The 10 countries in our sample are: Austria, Belgium, Finland, France, Germany, Italy, the Netherlands, Spain, Sweden, and the UK. Except for Sweden and the UK all countries joined the EURO in January 1999 and show a clear convergence of short and long-term interest rates in the 1990s (Schettkat 1999). We expressed all prices in ECU (the predecessor of the EURO, which was a weighted average of national currencies) using the exchange rate of the national currency to the ECU in $1996 .^{4}$

\footnotetext{
3 Haskel and Wolf (2001) also make use of IKEA data but they concentrate on low-price items including only one high-price item (a sofa) and they do not restrict their sample to EU countries and thus have their data affected by formal trade barriers.

5 The exchange rates are: 13.43 (Austria), 39.30 (Belgium), 0.81 (England), 5.83 (Finland), 6.49 (France), 1.91 (Germany), 1959 (Italy), 2.14 (The Netherlands), 160.8 (Spain), and 8.51 (Sweden). We use 1996 because prices for the 1997 catalogues are most likely determined in 1996. Using 1997, however, will not change the results.
} 
IKEA not only designs the furniture centrally - mainly in Sweden- and sells them under the same Swedish name, but they also produce the furniture (or led produce) for a world-wide market, they have central marketing - their catalogues are fairly identical within the EU-countries -, they minimize transport costs by flat packaging, and they operate stores almost identical around Europe. Shopping is largely self-service and customers have to transport and assemble the furniture themselves. IKEA sets prices at the national level published in an annual catalogue, short-run demand variations as emphasized in the menu-cost literature are therefore not relevant in our case. All stores within one country sell identical products at the same price published in the IKEA catalogue. IKEA products are truly homogeneous not only with respect to the products themselves but also regarding the shopping environment and the services delivered. The products are distinguished by 14 product groups, which are: sofas, wardrobes, storage and bookcases, junior beds, bedroom suites, armchairs, home office furniture, chests of drawers, and accessories in halls and entrance, floors and walls, lighting, interior textiles, gifts and miscellaneous. In sum, the empirical analysis is based on 2220 observation, which are derived from 222 items that are sold in 10 EU countries.

To test hypothesis 4 (second degree price discrimination) we make use of a second panel data set constructed from IKEA catalogues for 1997/ 1998 and 2000/2001. The data set is similar to the one described before but covers only 89 products from 9 EU-countries (the countries from above without Belgium). The data characteristics are almost identical to the ones of the former data.

We eliminate between-product price variation, which stems from the intrinsic diversity of the products and focus on the between-country variation, which potentially reflects price-setting 
policy. We calculate the difference in national prices relative to the European average for each product.

$$
\mathrm{M}=\mathrm{p}_{\mathrm{i}, \mathrm{c}}^{*} / \mathrm{p}_{\mathrm{i}, .}^{*}-1 ; \quad \mathrm{i}=1, \ldots, 222, \mathrm{c}=1, \ldots, 10
$$

where $\mathrm{p}^{*}$ is the price expressed in ECU, subscript i refers to the product, subscript $\mathrm{c}$ refers to the country, and $\mathrm{p}_{\mathrm{i}}{ }_{\text {, }}$, refers to the mean European price of item i.

Figure 1 shows the distribution of M based on 2220 observations. The dispersion of the distribution is remarkable. 93 percent of the observations are in the 25-percent interval around the mean but this is a remarkable 50 percentage-points range in price! The average price range $\left(\mathrm{p}^{*}{ }_{\text {max }}-\mathrm{p}^{*}\right.$ min $)$ over all 222 products is 44 percent and the coefficient of variation for individual products varies from 0.049 to 0.433 with a mean of $0.136 .{ }^{5}$ However, Figure 2 shows the expected decline in the coefficient of variation with the average product price. The distribution displayed in Figure 1 is for sure not expected if the EU countries were actually an integrated market.

\section{Testing the hypotheses}

Our empirical model is based on equation (1"), for which we use the log-differences of country-specific prices as the independent variables:

$$
\mathrm{y}_{\mathrm{i}, \mathrm{c}}=\Sigma_{\mathrm{i}} \Sigma_{\mathrm{c}} \beta_{\mathrm{i}, \mathrm{c}} \mathrm{d}_{\mathrm{i}, \mathrm{c}}+\varepsilon_{\mathrm{i}, \mathrm{c}} \quad \mathrm{i}=1, \ldots, 222 ; \mathrm{c}=1, \ldots, 10
$$

5 The coefficient of variation computed as CV.,. $=1 / 222 \Sigma_{\mathrm{i}}\left[1 / 9 \Sigma_{\mathrm{c}}\left(\mathrm{p}_{\mathrm{i}, \mathrm{c}}^{*}-\mathrm{p}_{\mathrm{i} .}^{*}\right)^{2}\right]^{1 / 2} / \mathrm{p}_{\mathrm{i}}^{*}$ 
where: $\mathrm{y}_{\mathrm{i}, \mathrm{c}}=\ln \left(\mathrm{p}_{\mathrm{i}, \mathrm{c}}^{*}\right)-\ln \left(\mathrm{p}_{\mathrm{i}, \mathrm{f}}^{*}\right) ; \varepsilon$ is a stochastic error term assumed to be normally distributed. The dependent variable thus gives the percentage difference of the price in the c-th country relative to the mean price $\left(\mathrm{p}_{\mathrm{i}, \text {, }}{ }^{6}{ }^{6}\right.$ Equation (2) will be used to test the four hypotheses, by putting various restrictions on the parameters $\beta_{\mathrm{i}, \mathrm{c}}$ of the 2220 dummy variables $\mathrm{d}$.

\section{Hypothesis 1: Law of one price or strong PPP version}

Our first hypothesis is the strongest: common-currency prices for specific products are the same in every country. That is that the coefficients for all country dummies are zero.

$$
\begin{array}{ll}
\mathrm{H}_{\mathrm{o}}: & \beta_{., \mathrm{c}}=0, \forall \mathrm{c} \\
\mathrm{H}_{\mathrm{a}}: & \beta_{., \mathrm{c}} \neq 0
\end{array}
$$

Under the null hypothesis the country effects are zero and the alternative hypothesis postulates that country specific effects exists, which may differ across countries. We estimated equation (2) with the restriction $\beta_{\mathrm{i}, \mathrm{c}}=\beta_{\mathrm{j}, \mathrm{c}}$, so that we have 10 country dummies in the unrestricted model. The F-test (see bottom of Table 1 , model I) on $\beta_{\text {.,c }}=0, \forall$ c clearly rejects the null hypothesis. LOP does definitely not prevail.

\section{Hypothesis 2: Country-specific price setting (relative LOP) or weak PPP version}

We next investigate the weak PPP version in more detail. Prices may vary systematically among countries because of country-specific costs in the non-tradable cost components or other country-

6 Note that the dependent variable captures the variation within products between countries but not the variation between heterogeneous products. A test on product-specific effects is rejected at the 5 percent level. 
specific effects (such as country-specific differences in competition etc.). Do country specific price levels vary with non-tradable cost components?

$$
\begin{array}{ll}
\mathrm{H}_{\mathrm{o}}: & \beta_{., \mathrm{c}}=0, \forall \mathrm{c} \\
& \gamma \neq 0 \\
\mathrm{H}_{\mathrm{a}}: & \beta_{., \mathrm{c}} \neq 0 \\
& \gamma \neq 0
\end{array}
$$

where $\gamma$ refers to the coefficients of the non-tradable cost variables, labor costs and VAT in the regression equation.

The estimated country effects under the restriction $\gamma=0$ (which actually is the $\mathrm{H}_{\mathrm{a}}$ of hypothesis 1 ) are displayed in Table 1 model I. France has the highest price level (+6.1\%) and Sweden has the lowest price level (-6.1\%). The range of the country effects is about 12 percentage-points, which is a fairly narrow range. But the model explains only about 9 percent of the inter-country price variation (recall that we eliminated price differences between products), which does not increase if we include cost variables such as labor costs (from Eurostat 1997) and the VAT (model II in Table 1). The country coefficients change slightly but the ranking of the countries as well as the difference between the highest and the lowest price remain unchanged suggesting that beside differences in costs of non-tradable components other variables may affect price setting. 
Table 1: Test of the weak PPP version

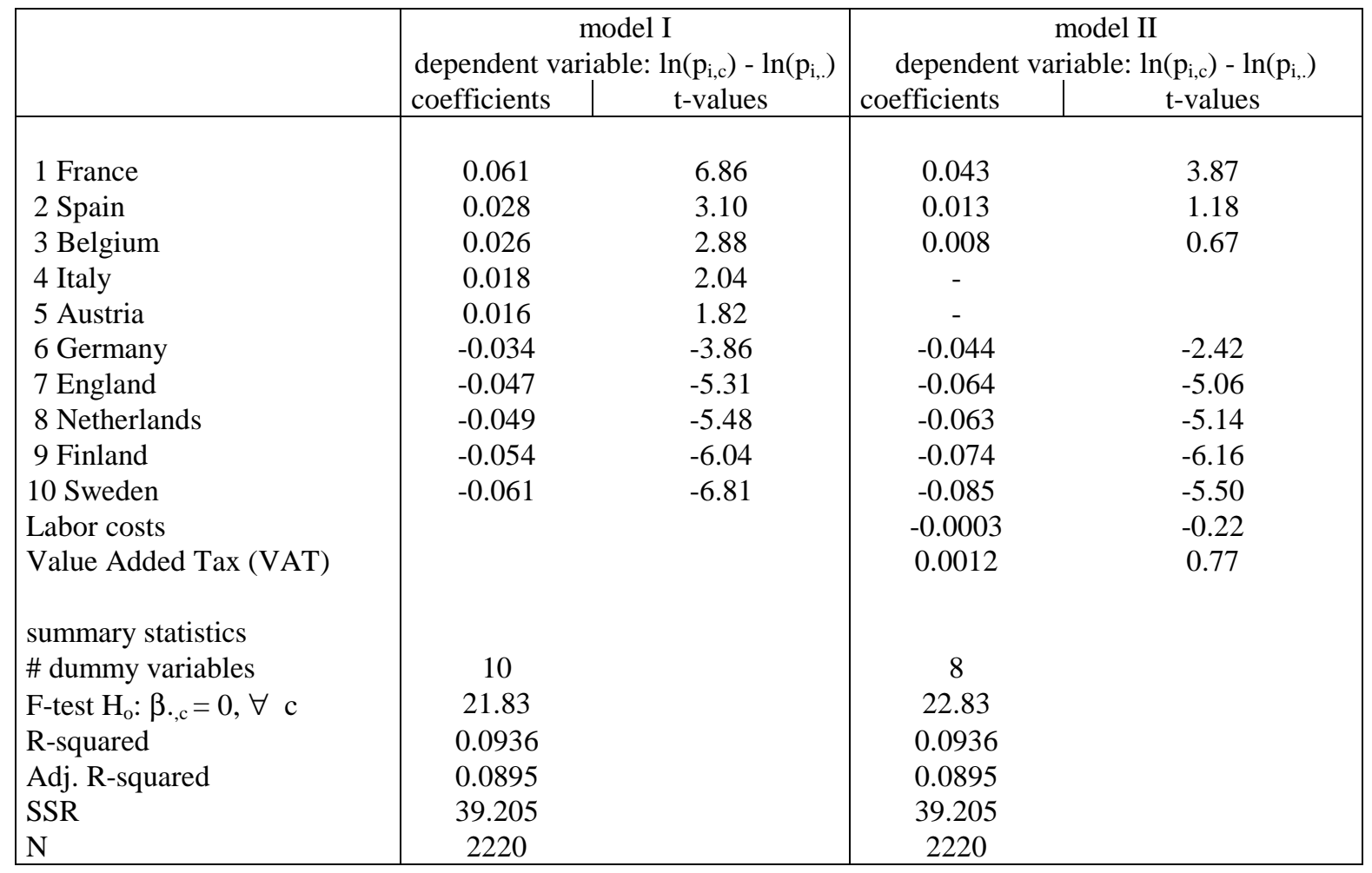

\section{Hypothesis 3: Pricing to the market (mach I) or third degree price discrimination}

With 'pricing to the market' firms try to price-discriminate between national markets according to the national differences in the price-elasticity of demand. The requirement, of course, is a sufficiently large difference in national consumer behavior observable to the seller. Probably consumers in one country have a stronger preference for say kitchen furniture than consumers in another countries, which than should be revealed in country-specific price effects for product groups. In this case, market segmentation will be based on different demand elasticities for product groups, which leads to markups differing by country and product group. In other words, the restrictions on the coefficients displayed in the alternative hypothesis above.

$$
\mathrm{H}_{\mathrm{o}}: \quad \beta_{\mathrm{i}, \mathrm{c}}=\beta_{\mathrm{j}, \mathrm{c}}
$$




$$
\mathrm{H}_{\mathrm{a}}: \quad \beta_{\mathrm{i}, \mathrm{c}}=\beta_{\mathrm{j}, \mathrm{c}} \quad \forall \mathrm{i}, \mathrm{j} \in \mathrm{g}
$$

The null hypothesis means that the country effects are identical for all products in one country assuming that non-tradable cost components affect all products proportional to the mean price.

The estimation of equation (3), with $\beta_{\mathrm{i}, \mathrm{c}}=\beta_{\mathrm{j}, \mathrm{c}}(\forall \mathrm{i}, \mathrm{j} \in \mathrm{g})$ requires dummy variables for each country and each product group (140 dummy variables). The restriction on the coefficient means that we test whether the country effects are identical within the product groups but that they differ between the product groups. The F-test (2.77, 130 variables and 2080 degrees of freedom) rejects the null hypothesis that pricing is purely country-specific. Thus, there is evidence that pricing to the market mach I, price discrimination between countries by product groups occurs. Prices vary systematically between the EU-countries within product groups. However, the model explains only 25 percent of the variance, leaving a huge 75 percent unexplained, which may be caused by more sophisticated product-by-product price discrimination (pricing to the market, mach II).

\section{Hypothesis 4: Pricing to the market (mach II) or second degree price discrimination}

Pricing to the market according to country-specific demand functions for individual products requires a very high degree of information on the seller's side. In an extreme view assuming full information the seller knows the demand function for every product at any time and can thus change prices with possible changes in the price elasticity. In this case, however, price discrimination mach II cannot be distinguished from arbitrary price setting for the outside observer. More realistic, but still requiring substantial information, is to assume that the seller tries to estimate the actual price elasticity which is assumed to be constant. In this case price 
discrimination is not 'perfect' but we expect systematic price differences between countries for identical products to persist.

To test for product-specific price discrimination we use equation (2) and implement the following regression model:

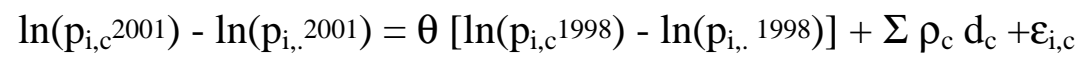

where $\ln \left(\mathrm{p}_{\mathrm{i}, \mathrm{c}} 1998\right)-\ln \left(\mathrm{p}_{\mathrm{i}, .}\right.$ 1998) is the $\log$ difference in price of item $\mathrm{i}$ in country $\mathrm{c}$ to the mean price of this item in 1998, 2001 respectively.

$\mathrm{H}_{0}: \quad \theta=1$

$\mathrm{H}_{\mathrm{a}}: \quad \theta<1$

Table 2 displays the results of this regression. The F-test clearly rejects $\mathrm{H}_{0}$, we do not observe 'perfectly' constant relative prices over time but the coefficient for relative prices in the first period is highly significant although with .53 substantially below the 1.0 expected under the Null. Furthermore, country dummies are significant, which means that there are systematic country effects in the changes of prices. Finland and Spain (high-price countries in 1998) experienced a relative price rise, whereas prices in England, France, Germany and Italy fell. Our result is consistent with country-specific and item-specific price discrimination under imperfect information. If the IKEA does not know the country-specific price elasticity but tries to approach it, we would expect the coefficient $\theta$ to be significant but lower than one. 
Table 2: Test on hypothesis 4, Panel Sample

\begin{tabular}{|c|c|c|}
\hline & \multicolumn{2}{|c|}{$\begin{array}{l}\text { Dependent variable: } \\
\ln \left(\mathrm{p}_{\mathrm{i}, \mathrm{c}} 2001\right)-\ln \left(\mathrm{p}_{\mathrm{i}, .}, 2001\right)\end{array}$} \\
\hline & coefficients & t-values \\
\hline 1 Finland & 0.040 & 2.71 \\
\hline 2 Austria & 0.030 & 1.98 \\
\hline 3 Spain & 0.015 & 1.01 \\
\hline 4 Netherlands & -0.009 & -0.63 \\
\hline 5 Sweden & -0.017 & -1.15 \\
\hline 6 England & -0.026 & -1.73 \\
\hline 7 France & -0.028 & -1.90 \\
\hline 8 Germany & -0.038 & -2.56 \\
\hline 9 Italy & -0.068 & -4.52 \\
\hline $\ln \left(\mathrm{p}_{\mathrm{i}, \mathrm{c}} 1998\right)-\ln \left(\mathrm{p}_{\mathrm{i}, .}{ }^{1998}\right)$ & 0.534 & 15.97 \\
\hline summary statistics & & \\
\hline \# dummy variables & 9 & \\
\hline F-test $\mathrm{H}_{\mathrm{o}}: \rho_{\mathrm{c}}, \theta=0, \forall \mathrm{c}$ & 32.11 & \\
\hline R-squared & 0.1736 & \\
\hline Adj. R-squared & 0.1682 & \\
\hline SSR & 57.759 & \\
\hline $\mathrm{N}$ & 1538 & \\
\hline
\end{tabular}

\section{Conclusions}

This study strongly supports the view that deviations from the 'law of one price' are not just the result of measurement error - that is non-identical products with respect to the quality of the product, bundling etc.- but that price discrimination between national market is part of the pricing strategies of profit-maximizing firms with some price-setting power. For identical products we find product-group and even product-specific price discrimination between countries. Since we restrict the analysis to countries of the EU we can exclude formal trade and regulatory policies as causes for the observed price discrimination. This study provides evidence that profit-maximizing price discrimination is aimed at but that the actual demand curves are blurred for the seller due to imperfect information. 
We get four remarkable outcomes: 1) The law of one price does not hold. 2) Country-specific effects of non-tradable cost components are important. 3) Pricing to the market surely occurs but price discrimination is limited by incomplete information. 4) The unexplained part of betweencountry price variation for identical products is about $75 \%$ which leaves most of the inter-country price variation unexplained. 


\section{References}

Blinder, A.S., Canetti, E.D., Lebow, D. E., Rudd, J.B. (1998) Asking About Prices. New York: Russel Sage Foundation.

Dornbusch, R., 1987, Purchasing Power Parity, Palgrave's Dictionary of Economics, London: Macmillan.

Froot, K., Kim, M., Rogoff, K. (1995) The law of one price over 700 years, NBER Working Paper \#5132, May, Cambridge, Mass.: NBER.

Goldberg, P., Knetter, M. (1997) Goods Prices and Exchange Rates: What Have We Learned?, Journal of Economic Literature, Vol. XXXV, September, 1243-1272.

Goldberg, P. and Verboven, F. (1998) "The Evolution of Price Dispersion in the European Car Market," NBER Working Paper No. 6818.

Gosh, A.R. and Wolf H.C. (1994), "Pricing in International Markets: Lessons From The Economist, NBER Working Paper No. 4806.

Hall, R.L. and Hitch, C.J. (1939), "Price Theory and Business Behaviour," Oxford Economic Papers, Vol 2.

Haskel, J., Wolf, H. (2001), The Law of One Price - A Case Study, NBER working paper 8112, National Bureau of Economic Research, Cambridge, Mass.

Isard, P. (1977), How Far Can We Push the Law of One Price? American Economic Review, 942-948.

Kasa, K. (1992) Adjustment Costs and Pricing-to-Market: Theory and Evidence, Journal of International Economics, Vol. 32, No. 1-2, Feb., 1-30.

Knetter, M.M. (1989) Price Discrimination by US and German Exporters, American Economic Review, Vol 79, March, 198-210.

Knetter, M.M. (1997), “The Segmentation of International Markets: Evidence from The Economist” NBER Working Paper No. 5878.

Kravis, I., Lipsey, R. (1977) Export Prices and the Transmission of Inflation, American Economic Review, Febr., 155-163.

Krugman, P. (1987) Pricing to Market Where the Exchange Rate Changes, in: Arndt, S.W., Richardson, J.D. (eds.) Real Financial Linkages Among Open Economies, Cambridge, Mass.: MIT Press, 49-70.

Okun, A. M. (1981). Product markets. Prices \& Quantities: a macroeconomic analysis (pp. 134-181). Washington DC: The Brookings Institution.

Pigou, A.C., 1920, The Economics of Welfare, 4th edition, London: Macmillan.

Rogoff, K. (1996) The Purchasing Power Parity Puzzle, Journal of Economic Literature, June 1996, 647-668.

Shapiro, C., Varian H. (1999) Information Rules, Cambridge, Mass.: Harvard Business School Press. 
Stiglitz, J., 1991, Price rigidities and market structure, in Mankiw, G./ Romer, D. (eds.) New Keynesian Economics, vol. 2, Coordination failures and real rigidities, Cambridge, Mass.: MIT Press: 377-386.

Varian, H. R. (1989) Price Discrimination, R. Schmalensee, Willig, R., Handbook of Industrial Organization. Amsterdam: North Holland Press, 1989, pp 600-654.

Verboven, F. (1996) International Price Discrimination in the European Car Market, Rand Journal of Economics, Vol. 27, No.2, Summer, 240-268. 
Figure 1 - Empirical distribution of M1; 2220 observations

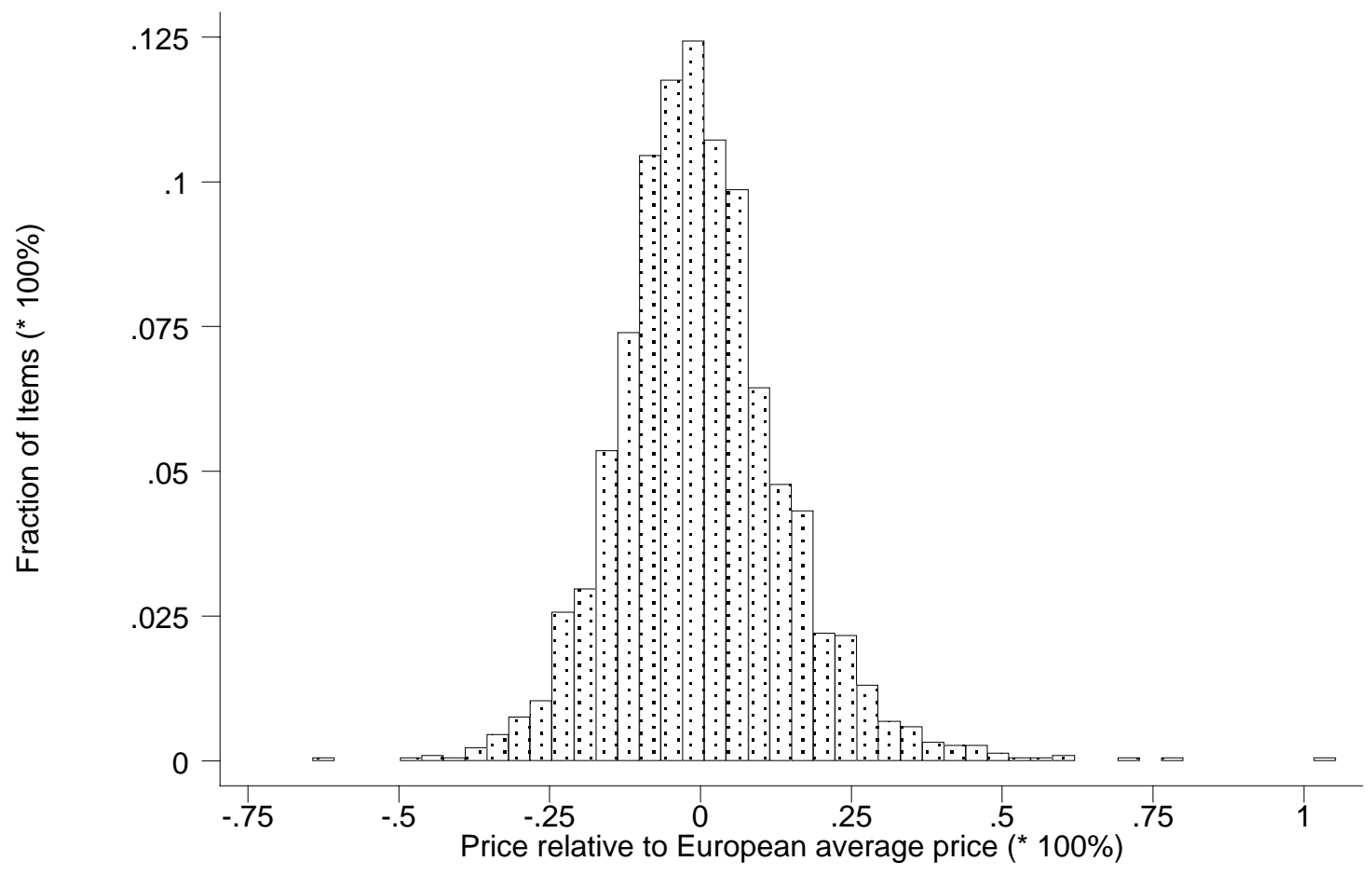


Figure 2 - Mean price versus coefficient of variation (CV), 222 items

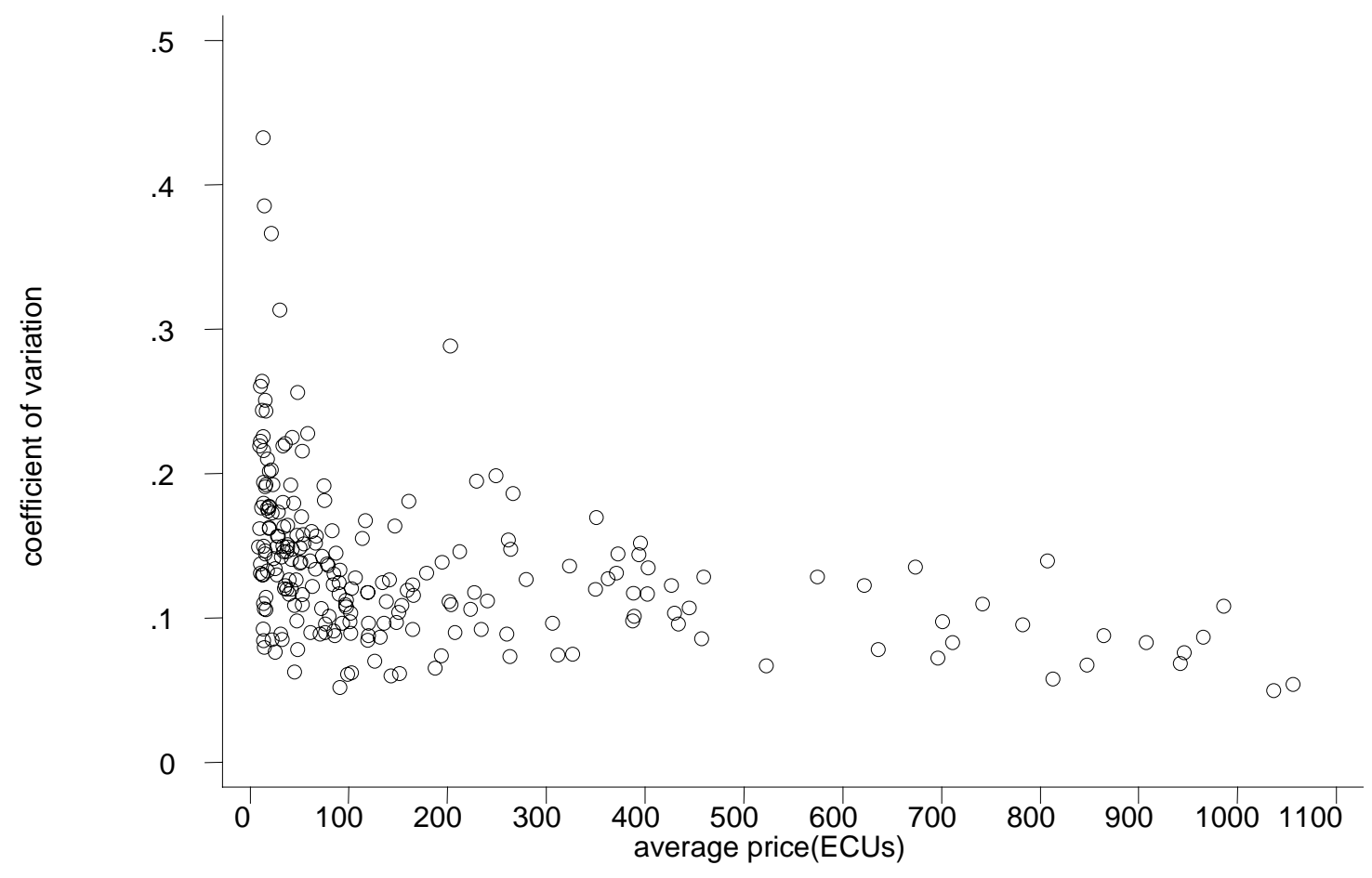




\section{IZA Discussion Papers}

\section{No Author(s)}

231

G. Saint-Paul

232

E. Bardasi

M. Francesconi

233

C. Dustmann

C. M. Schmidt

234 R. Rotte

M. Steininger

235 W. Schnedler

236 R. Hujer

M. Caliendo

237 S. Klasen

I. Woolard

238 R. Euwals

A. Börsch-Supan

A. Eymann

239 F. Andersson

K. A. Konrad

240

W. Koeniger

241

W. Koeniger

242
G. Faggio
J. Konings

243

E. Brainerd

244

S. M. Fuess, Jr. M. Millea
Titel

Area

Date

The Economics of Human Cloning

5

$12 / 00$

The Effect of Non-Standard Employment on

5

$12 / 00$

Mental Health in Britain

The Wage Performance of Immigrant Women:

Full-Time Jobs, Part-Time Jobs, and the Role of

Selection

Sozioökonomische Determinanten extremistischer 3

$12 / 00$

Wahlerfolge in Deutschland: Das Beispiel der Europawahlen 1994 und 1999

Who gets the Reward? An Empirical Exploration

of Bonus Pay and Task Characteristics

Evaluation of Active Labour Market Policy:

6

$12 / 00$

Methodological Concepts and Empirical

Estimates

Surviving Unemployment without State Support:

3

$12 / 00$

South Africa

The Saving Behaviour of Two Person House-

5

$12 / 00$

holds: Evidence from Dutch Panel Data

Human Capital Investment and Globalization in

5

01/01

Extortionary States

Labor and Financial Market Interactions: The the UK 1969-95

Trade, Labor Market Rigidities, and GovernmentFinanced Technological Change

$01 / 01$

Job Creation, Job Destruction and Employment

4

$01 / 01$

Growth in Transition Countries in the 90's

Economic Reform and Mortality in the Former

4

$01 / 01$ Soviet Union: A Study of the Suicide Epidemic in the 1990s

Pay and Productivity in a Corporatist Economy: Evidence from Austria 
The Optimal Level and Composition of Retirement Benefit Systems

250 T. J. Hatton

J. G. Williamson

Demographic and Economic Pressure on

Emigration out of Africa

01/01

251 R. Yemtsov

Labor Markets, Inequality and Poverty in Georgia

$01 / 01$

252 R. Yemtsov

Inequality and Income Distribution in Georgia

$01 / 01$

253 R. Yemtsov

Living Standards and Economic Vulnerability in Turkey between 1987 and 1994 
263 N. Datta Gupta

N. Smith

264

C. Dustmann

265

M. Rosholm

M. Svarer

266 C. Dustmann

O. Kirchkamp

267 A. Newell

268

A. Newell

B. Reilly

269

H. Buddelmeyer

270

B. Augurzky

C. M. Schmidt

271 B. Augurzky

C. M. Schmidt

272 C. Belzil

J. Hansen

273 G. Saint-Paul

274

P. J. Pedersen

N. Smith

275 G. S. Epstein

T. Lecker

276

B. Amable

D. Gatti
Children and Career Interruptions:

The Family Gap in Denmark

5

$02 / 01$

Return Migration, Wage Differentials, and the 1

$02 / 01$

Optimal Migration Duration

Structurally Dependent Competing Risks

$02 / 01$

The Optimal Migration Duration and Activity

$02 / 01$

Choice after Re-migration

The Distribution of Wages in Transition Countries

4

$03 / 01$

The Gender Pay Gap in the Transition from

4

03/01

Communism: Some Empirical Evidence

Re-employment Dynamics of Disabled Workers

3

03/01

The Evaluation of Community-Based

6

$03 / 01$

Interventions: A Monte Carlo Study

The Propensity Score: A Means to An End

6

03/01

Heterogeneous Returns to Human Capital and

5

03/01

Dynamic Self-Selection

Distribution and Growth in an Economy with

5

$03 / 01$ Limited Needs

Unemployment Traps: Do Financial Dis-

3

$03 / 01$

incentives Matter?

Multi-Generation Model of Immigrant Earnings

03/01

Theory and Application

The Impact of Product Market Competition on

5

03/01 Employment and Wages 

national Integration

klund

S. Vroman

283 M. Hagedorn
A. Kaul

V. Reinthaler

Welfare Analysis in a Schumpeterian Growth to Internal Promotion for Young U.S. Men and Women Living Arrangements 

and the Rising Returns to Skill: US and France 1964-2000

293 D. Cobb-Clark T. F. Crossley

294 Š. Jurajda

N. Smith

L. Husted

297 J. C. van Ours J. Veenman

P. Cahuc

E. Wasmer
Gender, Comparative Advantage and Labor Market Activity in Immigrant Families Insurance Compensation on the Labor Market Histories of Displaced Workers

Individual Pay and Outside Options:

Intergenerational Transmissions and the Schoolto-Work transition of $2^{\text {nd }}$ Generation Immigrants

The Educational Attainment of Second Generation 1 Immigrants in The Netherlands

Returns to Education and Wage Equations and Subjective Well-Being The Role of Social Work

Economic and Social Perspectives of Immigrant 06/01 Children in Germany 

H. Bonin
G. Abío
E. Berenguer
J. Gil
C. Patxot

G. A. Pfann

D. S. Hamermesh
Is the Deficit under Control? A Generational Chronic Diseases: An Alternative Model for Monetary Appraisal 